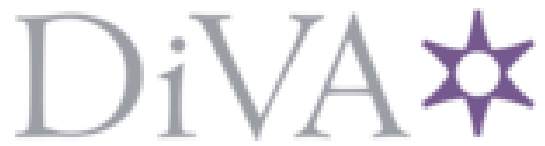

http://www.diva-portal.org

This is the published version of a paper published in Current Sociology.

Citation for the original published paper (version of record):

Hearn, J., Strid, S., Husu, L., Verloo, M. (2016)

Interrogating violence against women and state violence policy: Gendered intersectionalities and the quality of policy in The Netherlands, Sweden and the UK Current Sociology, 64(4): 551-567

https://doi.org/10.1177/o011392116639220

Access to the published version may require subscription.

N.B. When citing this work, cite the original published paper.

Permanent link to this version:

http://urn.kb.se/resolve?urn=urn:nbn:se:oru:diva-51050 


\title{
Interrogating violence against women and state violence policy: Gendered intersectionalities and the quality of policy in The Netherlands, Sweden and the UK
}

Current Sociology Monograph 2016, Vol. 64(4) 55I-567 (C) The Author(s) 2016

Reprints and permissions: sagepub.co.uk/journalsPermissions.nav DOI: 10.1177/001।3921।6639220

\section{Jeff Hearn}

Örebro University, Sweden; Hanken School of Economics, Finland; University of Huddersfield, UK

\section{Sofia Strid}

Örebro University, Sweden

\author{
Liisa Husu \\ Örebro University, Sweden
}

\section{Mieke Verloo}

Radboud University, The Netherlands

\begin{abstract}
This article builds on feminist scholarship on intersectionality to address violence against women, and state policy thereon. It takes up the challenge of analysing the complex, situated and spatial relationship between theorizing on violence against women and state policy on such violence. Drawing on extensive comparative European data, it explores the relations of gender and intersectionality, conceptualized as gendered intersectionalities, by examining how multiple inequalities are made visible and invisible
\end{abstract}

\section{Corresponding author:}

Jeff Hearn, Gender Studies/Centre for Feminist Social Studies, Örebro University, Örebro, SE-70I 82,

Sweden.

Email: jeff.hearn@oru.se 
in state policy and debates in the Netherlands, Sweden and the UK. Attention is paid to different forms of gendered intersectionalities in policy, for example, tendencies to degender violence against women. A key aim of the article is to investigate how comparative analysis can be a starting point for assessing if, how and to what extent the inclusion of multiple inequalities could increase the quality of policy, for both reducing and stopping violence, and assisting those subject to violence.

\section{Keywords}

Comparative, Europe, intersectionality, policy, violence against women

\section{Introduction}

This article builds on the rich, diverse feminist traditions of theorizing on intersectionality, including tensions between these traditions, to examine key gender concerns, namely violence against women, and state policy thereon. Translating such theoretical complexity into policy and practice is a major challenge. Here specifically we interrogate the relations of gender and intersectionality, conceptualized as gendered intersectionalities, by examining and comparing how multiple inequalities are made visible and invisible in state policy and debates in the Netherlands, Sweden and the UK. Attention is paid to different forms of gendered intersectionalities in policy, for example, tendencies to degender violence against women. Such analysis can be a means for assessing if, how and to what extent inclusion of multiple inequalities could increase the quality of policy, both for reducing and stopping violence, and assisting those subjected to violence.

\section{Intersectionality and violence against women}

The term 'violence against women' denotes violence that is directed towards women because they are women (Watts and Zimmermann, 2002); it is a clearly gendered category; it is not degendered. This framing recognizes the structural element of violence; violence is shaped by and structures social positions and gender orders, and serves to maintain inequality. Violence against women is not explained primarily by psychological or pathological characteristics of individual perpetrators or dysfunctional families, but is reconceptualized as a form of power, inequality and control.

What might be called the violence against women movement, involving a mixture of activism, political work, policy development and research, has addressed gendered intersectionalities regarding race, class, nationality, sexuality, age and disability for many years, stressing intersections of gender with class, ethnicity and racialization (Abraham, 2000; Sokoloff and Dupont, 2005). As Dominguez and Menjivar (2014) show, low income minority ethnic and racialized women can be most disadvantaged and subjected to violent structures, making them more vulnerable to interpersonal violence. Relative disadvantage on one social dimension is likely to increase vulnerability to interpersonal violence, for example, through lack of resources affected by class and racialized subordination. Increasingly, intersections of gender with other inequalities, such as age, disability, indigeneity and rurality, are being considered. 


\section{Intersectionality, violence against women, inequalities and the quality of policy}

Our focus in this article is on violence, seen as inequality (Hearn, 2013). Violence is itself a form of social inequality, an unequal(izing) social structural division and relation of its own, a social distribution of who does what to whom. Violent practices link with social divisions and inequalities, class positions and other social intersections, as enactments of superordinate power, resistance to subordination and/or enactments of relative power in positions of subordination. Violence can be the reproduction of raw, unchallenged power, and/or reassertion of power in the face of resistance and possible loss of relative power. Accordingly, practices in the state, religion, media and other institutions, nationally and transnationally, are powerful in setting agendas of systems of differentiations and recognitions of violence. Gender domination persists in violent institutions and state control of violence, in constructions, identification, naming and defining violence. The very construction of what counts as violence is related to historical relations of gender power, social divisions, ideology and hegemony.

To enhance the quality of anti-violence policy it matters what inequalities are considered, and how these inequalities and their relations are conceptualized and linked to violence. Carol Bacchi (1999: 2) asserts that policies constitute 'competing interpretations or representations of political issues', and proposes a 'what's the problem?' approach to policy analysis - 'what presuppositions are implied or taken for granted in the problem representation which is offered; and what effects are connected to this representation of the "problem",

In this view, much policy and policy development can be understood as policy on gender and gender relations (Hearn and McKie, 2008). A common example here is that violence against women is often constructed as, and only as, domestic violence. This suggests an apparent demarcation of the private and the public, obscuring dynamic, fluid interactions between those realms. It limits the potential to tackle the interweaving of public and private, and related gender hierarchies. Interpersonal violence against women crosses 'social spaces' in several ways: first, there is the risk of violence after separation; second, in some countries most men arrested for domestic violence do not live with the woman they abuse; third, governments vary greatly in how domestic violence laws, governmental and other organizational policies intervene in patriarchal autonomy over personal affairs, and shape gender relations; fourth, public/private distinctions can mask the capacity of men to draw on their greater share of public sphere resources to control women in their personal lives.

Taking intersectionality seriously in anti-violence policy requires making all forms of violence and intersections between inequalities more visible, albeit within a framework that keeps gender in focus, as well as how violence is caused by and results in intersectional inequalities (Strid et al., 2013; Verloo and Walby, 2012). It means avoiding the further stigmatizing of already marginalized groups, as when policies present certain forms of violence as 'culturalized', i.e. caused by cultural differences (e.g. female genital mutilation [FGM], dowry deaths and forced marriage; see Roggeband and Verloo, 2007; Rolandsen Augustín, 2011). The complex links between violence, power and inequalities are rarely expressed explicitly in 
policy (Krizsán et al., 2007). So how can the concept of intersectionality become more useful in practice? This is far from easy. Indeed, several scholars question the possibility of joining all power relations into a single analysis, and argue for the need to acknowledge that each social division has its own ontological base (Verloo, 2006; Walby, 2009; Walby et al., 2012b; Yuval-Davis, 2006). However, exclusion of multiple inequalities from policy (and policy analysis) risks producing lower quality policy. The quality of policy on violence against women rests on criteria such as: internal consistency between the diagnosis and prognosis of a policy problem (Lombardo and Meier, 2009; Verloo, 2007); explicit gendering (Dombos et al., 2009; Fernández de Vega et al., 2010 [2008]); comprehensiveness of policy (Walby, 2009); and non-marginalizing intersectional inclusion which refers to the inclusion of multiple inequalities through naming and visibility (Dombos et al., 2009; Van der Haar and Verloo, 2013; Walby, 2007).

\section{Comparative European material}

Violence, and 'the problem of violence', is framed differently in different European countries. There is no unified, coherent policy on violence against women in Europe or in the EU. Though contested, the EU lacks legal competence in the domain of violence, and the Council of Europe builds on agreements between its members and promotes human rights through conventions, most importantly the Istanbul Convention (2011). There is no legally binding overall common approach to violence against women within the EU. The EU defines gender-based violence, including gender-based violence against women, as both a form of discrimination and a violation of the victim's fundamental freedoms (EC, 2014). The 'gender-based' element means that it is defined as violence directed against a person because of their gender or gender identity/expression, or as violence that affects persons of a particular gender disproportionately. Violence against women and girls is the most common form of gender-based violence. It is estimated that in Europe, $20-25 \%$ of women will have suffered physical violence at least once during their lives (CoE, 2006). In the EU context, violence against women has shifted from being framed as a health issue (Fernández de Vega et al., 2010 [2008]) to more recently being framed as an equality issue; violence against women is framed as being a consequence of the inequalities between women and men, as well as an obstacle to equality (EC, 2014).

At the nation-state level, within Europe, there is large variation in both gender equality policies and how intensely the issue of violence against women has been addressed. The empirical material we draw on here is based on the analysis of policy documents on violence against women, including laws, policy plans, parliamentary debates and civil society texts from the Netherlands, Sweden and the UK. These three European countries are interesting to compare as they show significant differences in terms of gender history and politics, relations of feminism and the state, and patterns of migration and colonialization (see Table 1). Such varying conditions demand great care in interpretation of comparative studies on violence, policy and violence policy. The policy data used are derived from the EU QUING project and cover the period 1995-2011 (QUING, 2007). Thus this article is partly historical, as 
Table I. Information on the three focus countries.

\begin{tabular}{|c|c|c|c|c|c|}
\hline Country & $\begin{array}{l}\text { Population } \\
\text { (millions) }\end{array}$ & $\begin{array}{l}\text { Income } \\
\text { inequality }\end{array}$ & $\begin{array}{l}\text { Global gender } \\
\text { gap rank }{ }^{\mathrm{b}}\end{array}$ & $\begin{array}{l}\text { Member of } \\
\text { European } \\
\text { Union }\end{array}$ & $\begin{array}{l}\text { Year and the inequality } \\
\text { first recognized in a } \\
\text { government body }\end{array}$ \\
\hline Netherlands & 16.8 & 30.9 & $14(0.7730)$ & 1958 & $\begin{array}{l}\text { Gender (Directorate } \\
\text { Coordination } \\
\text { Emancipation Policy 1978) }\end{array}$ \\
\hline Sweden & 9.6 & 25.0 & $4(0.8165)$ & 1995 & $\begin{array}{l}\text { Gender (Delegation } \\
\text { for Equality Between } \\
\text { Women and Men I972, } \\
\text { Equal Opportunities } \\
\text { Ombudsman 1980) }\end{array}$ \\
\hline UK & 64.1 & 36.0 & $26(0.7383)$ & 1973 & $\begin{array}{l}\text { Race (Race Relations } \\
\text { Board 1966) }\end{array}$ \\
\hline
\end{tabular}

${ }^{a}$ Gini index value according to United Nations Development Programme (UNDP) (20I4).

bWorld Economic Forum (20I4).

even since 2011 there have been significant developments, especially following the financial crisis and cutbacks in state support for anti-violence services, along with other policy changes. ${ }^{1}$

We now turn to the broad policy contexts and policy developments in violence against women policy in the three countries, then examine the range of inequalities and forms of gendered intersectionalities, and finally assess the specific question of degendering in these policies.

\section{Policy contexts and policy development}

The UK has a long history of feminist activism working to end violence against women, ${ }^{2}$ including feminist pressures put on the state, and feminist involvement in local and central policy development, with the women's refuge/shelter movement, with strong separatist traditions, increasingly operating in complex relations with state institutions. The first refuge for women and children who had experienced domestic violence was set up by the NGO Chiswick Women's Aid in 1971. The Women's Aid Federation of England was set up in 1974, and the following year the Home Affairs Select Committee on Violence in Marriage was initiated, leading to the Domestic Violence and Matrimonial Proceedings Act (England and Wales) 1976.

In policy documents from the UK, violence against women is described and conceptualized as being not only outright violence against women, but also violations of women's human rights, and as forms of oppression of women that support gender inequality. In the most recent policy plan, it is framed as a crime (Home Office, 2014). There are variations in the extent to which women and gender are named; or whether the debate is degendered (the more recent, the less degendered). Violence against women in the British policy context predominantly focuses on: domestic violence and violence in partnerships, sexual assault/violence and rape, harassment and stalking, forced marriage, female 
genital mutilation (FGM), honour crimes, and to a lesser extent trafficking. Prostitution is not framed as a form of violence.

There is no single comprehensive British legislation such as the Swedish Women's Peace Legislation or the US federal law Violence Against Women Act 1994 (renewed in 2013). Instead, legislation and policy address specific forms of violence against women (e.g. forced marriage), providing specific sanctions and remedies. 'Domestic violence' is not a specific offence under criminal law; rather many forms of domestic violence are codified as crimes (e.g. assault, false imprisonment, rape). Domestic violence is the most commonly addressed and recognized form of violence against women, often related to and framed as a problem of crime and crime prevention, and sometimes related to health or economic cost.

Recent policy initiatives include the Violence Against Women, Domestic Abuse and Sexual Violence (Wales) Act 2015 and, in both England and Wales, the criminalization of forced marriage (2014), strengthening of protections against stalking (2012) and, in 2003, tightened criminalization of FGM making it illegal for British nationals to perform FGM outside the UK (Female Genital Mutilation Act 2003). Since 9/11, there has also been stronger policy orientation towards problem formulations such as 'violence in the communities', which in the UK policy context means religion or ethnicity. Additionally, recent years have seen a mobilization by some men advocating the gender-neutralization of violence (against women), arguing that the use of violence is gender balanced.

In comparison, the Netherlands developed specific policies to combat violence against women in 1984 after the government invited feminist activists and policy makers together to set goals and create principles for state policy (Lauwers and Van der Wal, 2010). Their plan adopted a feminist analysis and framed violence against women as being a problem of unequal power relations between men and women, which was maintained by structural inequalities. The literal translation of violence policy from the early years is 'sexual violence against women' and included ill treatment of women; sexual abuse of children; sexual violence at work; sexual violence by care providers; pornography; prostitution; sex tourism; trafficking in women; violence against women refugees and ethnic minority women. Whereas these early policy plans had a specific gender focus, later policies gradually 'degendered' the problem, by turning attention to boys and men as (potential) victims as well, and de-emphasizing the gendered distribution of both victimization and abusing (Lauwers and Van der Wal, 2010). While the Netherlands have comprehensive policy plans for dealing with various forms of violence, there is no integral legislation covering all forms of violence against women. Dutch policy-making on violence is fragmented, predominantly 'soft' and degendered. 'Degendered' here means the practice of using ostensibly non-gendered terms to denote categories known to be gendered.

In Sweden, national laws against violence against women date back to the 13th century, with Birger Jarl's law on the protection of women and women's peace. More recent legislative initiatives in Sweden, addressing violence against women, can be dated from 1965 when marital rape was criminalized (Criminal Code, 1962).

Here violence against women is referred to as being a man's violence against a woman. Sweden is among the European countries with the most proactive policies on violence against women. It is the only European country in which legislation on men's violence against women is explicitly named (Kvist, 2010 [2008]). The Swedish government and 
parliament have, since 1991, defined violence against women as an expression of unequal power relations between men and women. There is a collective body of legislation gathered under the Women's Peace Legislation 1997 and violence against women has been a political concern since the 1970s (Regeringens Proposition 1997/1995:55). The offence of 'gross violation of integrity' was introduced in 1999 to address the complexity of harm experienced by women, and to criminalize the buying of sex (Regeringens Proposition 1998/99:145).

Honour-related violence, or what in the Swedish context is named 'violence and honour related oppression' (NCK, 2014), is included in policy relating to men's violence against women, it includes violence aimed at girls, young women, boys, young men and young LGBT persons. The predominant framing, or construction, of violence in the Swedish policy context is violence as a problem of gender equality and human rights. The Action Plan for Combating Men's Violence Against Women, Violence and Oppression in the Name of Honour and Violence in Same-Sex Relationships (Government Offices of Sweden, 2007) saw a shift in terms of the integration (though separate naming) of crimes based on honour and same-sex hate crimes, and the reframing of violence against women from being a problem of equality to an issue of serious crime.

Violence against women is a major social problem affecting the whole of society. Its being framed as a criminal issue is more prevalent among instances of rape and sexual violence than in other forms of violence against women. Swedish policy, however, also names and thus makes visible violence in close relationships, sexual violence and rape, FGM, honour crimes, prostitution, sexualization of public space (pornography), trafficking, and more recently forced and arranged marriages. This visibility of various forms of violence is not necessarily followed by the visibility of minoritized or marginalized groups of women, however. There is, for example, a strong heteronormative bias in Swedish policy on violence (Dahl, 2005).

\section{Range of intersectional inequalities}

Having outlined the relevant national policies, we may ask: what is the range of (intersecting) inequalities and social groups made visible and included, or excluded, in policy on violence against women? How are these constructed, and in relation to what problems?

In the British policy analysed, the most commonly named inequalities are ethnicity and age. Other intersections include religion and national/migrant status. Overall, class, sexual orientation, marital/family status and disability are considered less frequently. There are few intersections with gender; those named include intersections of ethnicity or race. Minority groups are named, for example, as minority ethnic or 'racial' groups (which include Roma); religion is used as a reference to minority or non-dominant religious groups, or to the moral preferences of the majority religion. Class is not explicitly given as an inequality, but there is reference to class inequality by the naming of 'lower-skilled', 'unemployed', 'economically disadvantaged groups', 'social exclusion/inclusion' and 'lone mothers'. Class remains important, even if not mentioned explicitly. There is direct naming of sexual orientation and references to gay, lesbian or bisexual people. There is reference to the specific forms of violence that can affect older people, youth, disabled 
people and lone mothers. The only inequalities intersecting with gender to a more than marginal extent are: ethnicity and age in policy on domestic violence and sexual violence; ethnicity in the civil society text on domestic violence; and age and disability in the law on sexual assault. Inequalities intersecting with inequalities other than gender are ethnicity and religion in policy on forced marriage (see Strid et al., 2010 [2008]).

From the early 2000 s, there has been an increasing political interest in the potential for community building, often based on faith communities and partnerships between government and voluntary bodies. There has also been interest shown in the roles of religious groups at the local level in community development and their social capital forming potential, which have been emphasized (e.g. Farnell et al., 2003). Government interest was made visible both in the publication of the major report Working Together: Co-operation between Government and Faith Communities in 2004 (Home Office Faith Communities Unit, 2004) and in the commissioning of the Review of the Evidence Base on Faith Communities (Beckford et al., 2006).

In the Netherlands, several groups are identified at the point of intersection within the policy field of violence against women, but one group especially stands out, namely, ethnic minority women (Lauwers and Van der Wal, 2010). The most frequently intersecting inequalities in policy on violence against women are gender and ethnicity, and gender and age (where age is often an add-on as in 'women and girls', and shows up embedded within gender and ethnicity: 'Ethnic minority women and girls'). Gender intersects less frequently with citizenship status and family status. Intersections of gender with religion and sexual orientation are less frequent; intersections with class and disability are invisible.

Next to gender, the most important inequalities are ethnicity, age and citizenship status. Class, disability, sexual orientation and religion are absent. Lauwers and Van der Wal (2010: 58) note: 'We may conclude that ethnicized-gendered actors form an actor category in diagnosis more or less isolated from other actor groups in society. The "majority" group or "privileged" group is never seen as part of the problem. Ethnicized-gendered actors are a separate group that causes or is suffering from separate/own problems.' This means that groups at the intersection of gender and ethnicity are very visible - one could say they are hyper-visible - but that this cannot be seen as contributing to the quality of the policies involved. While there is indeed attention to the problems of these groups, at the same time they are singled out as belonging to a culture that is problematic as such, in a context that is already stigmatizing this culture and 'othering' them (see Roggeband and Verloo, 2007).

Both the Dutch and UK policies on violence against women are often embedded in an overall 'crime and justice' framework, indicating a focus on sanctioning rather than on support for victims. Moreover, attention to violence against women is linked to the specific labelling of certain types of violence as culturally specific (e.g. honour crimes, FGM and forced marriage). This form of hyper-visibility that is found in Dutch antiviolence policies related to gender shows the risks involved in singling out certain intersectional groups.

In the Swedish case, policy documents address gender, ethnicity, religious beliefs and sexuality (with reference to 'violence in same-sex relationships'). The Criminal Code requires more severe punishment of crimes motivated by hatred of a person due to that 
person's 'race, skin colour, nationality, ethnicity, religion/faith, sexual orientation or other similar circumstance' (Criminal Code, 1962: 29 § 2). One’s class or socioeconomic status does not seem to be considered as relating to issues of inequality in the Swedish policy context. This may be linked to the comparatively small income differences that have existed in recent years, as indicated by low Gini index values (UNDP, 2014). Specifically, it speaks to how the politics of class (in)equality is embedded, and in a sense taken for granted, in Swedish politics, welfare and the creation of the folkhem (people's home). ${ }^{3}$

In conclusion to this overview of the three countries, we note that 'race and ethnicity' are different labels for what are often similar social relations in the UK and the Netherlands. In the Netherlands, Islam-related ethnicities are the most strongly racialized. On the other hand, 'race' has been used most often in relation to Blackness/African descent, and is not visible in policy against violence. Especially in the UK and the Netherlands, age seems mostly embedded within other groups. In all countries there are some very significant absences of inequalities in relation to violence, such as a consideration for homosexuality and disability (with the exception of Sweden for the latter). Most striking is the low presence (UK), or almost absence (Netherlands, Sweden) of consideration for class as being an explicitly named inequality related to violence.

\section{The construction of gendered intersectionalities}

Turning more directly to gendered intersectionalities, additional questions arise: What is the importance of intersectionality in policy on violence against women? How is intersectionality constructed within this policy? How is it named? What range of terms and concepts are used to denote intersectionality or intersecting axes? How is intersectionality framed and practised?

In UK policy, the terms used to denote minoritized and marginalized women in policy include: disadvantaged women (Home Office, 2003); vulnerable women (Department for Communities and Local Government, 2007); women in the communities (Home Office, 2005b); homeless women (Home Office, 2003); economically disadvantaged women (Home Office, 2005a); lone mothers; lower skilled women; multiple disadvantaged; and vulnerable adults (see Strid et al., 2010 [2008]). These are all actor categories. Intersectionality is articulated as multiple discrimination or multiple disadvantaged in the UK national policy context (Strid et al., 2009). It is a mutually shaping understanding of intersectionality that is visible; in other words, inequalities shape each other (Walby et al., 2012a).

During the time period examined, and with the exception of the intersection of gender and ethnicity, intersectionality is generally not treated as central to policy on violence against women. This exception is particularly notable in the policy fields of forced marriage and FGM, both framed as a problem of 'the Other'. To some extent, this exception is also present in policy on domestic violence. In many cases, intersectionality is central to policy problem definitions, but it is not part of the policy solutions; intersectionality is important to the diagnosis of a problem, but not to the prognosis. Multiple disadvantages and discrimination are targeted in the introductions, forewords or executive summaries of policy documents, and in relation to violence described as a structural problem located 
within the civil society, and indeed as a problem of crime and justice for the polity. However, the proposed policy actions rarely target the consequences of intersecting multiple inequalities. On the rare occasions when they do, the prognosis and policy actions are not aimed at transforming the discriminatory structures. Rather, policy actions constitute special measures, programmes that target, for example, lone parents' housing or women in ethnic minority communities.

In the Netherlands, intersectionality is indicated predominantly through the mention of intersectional actor categories (Lauwers and Van der Wal, 2010). Given that the intersection with gender and ethnicity is the one that is most strongly present in the Netherlands, what then are the terms in which policy documents discuss and articulate it? The answer for this is given mostly based on policy plans, not laws, as the current legal texts on violence do not explicitly articulate intersectionality (Lauwers and Van der Wal, 2010). Domestic violence policies are degendered and mention mainly 'perpetrators' and 'victims'. If there are sections of the policy that are gendered then they tend to focus on ethnicity. The label used for this is 'allochthonous' women (Yanow and Van der Haar, 2013). The word allochthonous defines people as not 'from here' (as opposed to autochthonous, who are 'from here') and might be adequate for migrant persons, but is actually only used for anyone who has grandparents from a non-western country; accordingly, it often holds negative connotations within much mainstream discourse. Given this, the use of any such label easily contributes to further marginalization or stigmatization of an already marginalized or stigmatized group (Roggeband and Verloo, 2007).

Swedish policy uses the notion of 'particularly vulnerable groups' to denote intersectionality (2007 onwards, and in the Swedish Action Plan on Violence Against Women). The groups, actor categories, are constructed as particularly vulnerable and framed as being more important to target than other groups. These include women with mental and physical disabilities (gender/disability), older women (gender/age), younger women (gender/age), immigrant women (nationality/ethnicity/gender) and women with addiction or substance problems (gender/health). Swedish policy underlines the unity of the group, 'women victims of violence', and, at the same time, problematizes it:

Many who have personal experience of violence state that people focus more on their disabilities, their foreign background, their substance abuse/addiction or their age than on the fact that they have been assaulted. National minorities experience similar problems. The Government has viewed this situation with concern and wishes to make clear that all women exposed to violence must be given the requisite support and protection based on their needs, whoever they may be and whatever background they may have. (Government Offices of Sweden, 2007)

\section{Degendering: An intersectional paradox?}

An important aspect of moves to intersectional policy is that they may also sometimes, and paradoxically, bring with them a tendency towards degendering. In the case of the UK where, superficially, there may have appeared to be a lack of recognition of gender intersecting with other inequalities, caution is needed because of the process of degendering. Previously gendered categories became degendered in policy on violence against women under the last Labour governments (1997-2010). Examples of this 
include 'victim of domestic violence' and 'perpetrator of sexual assault'. When policy is degendered, there are no immediately visible intersections of gender and other inequalities. However, degendering is not the same as gender-neutrality. When not considering the full range of concepts used to denote multiple inequalities, there are no visible intersections between gender and other inequalities. Yet, when understanding that degendering is not necessarily an expression of gender-neutrality, but rather a strategic way of making policy inclusive, the policy debates are heavily infused with gendered intersectionalities. More recent policy is yet again explicitly gendered (Home Office, 2014).

In the Netherlands anti-violence policy on sexual harassment and domestic violence is often degendered, while policies against what is labelled 'honour-related violence' and FGM is not (Lauwers and Van der Wal, 2010). In the last case, gender is named in combination with ethnicity. Looking at the absences, class is a very clear absence in Dutch policies on violence. Lauwers and Van der Wal (2010: 47) see the absence of class in the issue of gender-based violence as related to the degendering of violence, especially domestic violence and sexual harassment, and to the unlinking of the genderbased violence documents from the notion of structural gender inequality in the Dutch Multi-Year Emancipation Policy Plan 2008-2011 (2007) where class is mentioned in the chapter on violence against women. This plan states that the social-economic dependence of women on men is a cause of the unequal power between the genders and that violence against women in turn is a consequence of this power difference. So in this generic gender equality plan the issue is gendered and linked to structural (power) inequalities between men and women in society, while in documents that are specifically dedicated to violence issues, this is not the case. In comparing how policy is degendered, the UK and the Netherlands appear to share a similar pattern of cultural bias: 'culturalized' forms of violence are gendered, whereas non-culturalized forms of violence are degendered. This raises further questions on how such bias relates to migration patterns and (post-)colonialization.

Swedish policy on violence against women was not degendered in the same way as British policy during the time period researched, nor does it show the 'hyper-visibility' of the intersection of gender and ethnicity as the Dutch policy. Rather, policy in Sweden is 'hyper-gendered': 'women' is the most common group referred to as victims of violence. Girls and young women are often mentioned in relation to honourrelated crimes, but also boys, bisexuals, homosexuals, transgendered persons and men. Honour-related crimes are described as different from other forms of violence due to their 'collective nature' with multiple perpetrators and victims. Perpetrators are predominantly named as men, with the exception for policy on same-sex violence, in which case perpetrators are non-gendered (Kvist, 2010 [2008]). Women are, therefore, not named as perpetrators.

Sexual violence could potentially be seen as marking an exception. The policy field has recently shown tendencies towards degendering. In general, and instead, there is a rather strong emphasis on women and on men, leading to other forms of exclusions, for example, violence in LGBT relationships. The categories 'women' and 'men' are referred to as two internally unified groups with mutually exclusive interests and living conditions. The lack of degendering of Swedish policy may follow from underlying understandings of a pervasive sex/gender power system. Instead of degendering, we see 
marginalization of minoritized and othered groups in Swedish gender equality policy generally and in policy on violence against women. The sex/gender power framing and strong focus on a unified, cohesive voice of 'women' may risk excluding voices of women who for various reasons do not fit the dominant norm.

\section{Conclusion}

This article has investigated various forms of gendered intersectionalities in policy. It has assessed how and to what extent the inclusion of multiple inequalities and intersectionalities could increase the quality of policy, for reducing and ending violence against women, as well as assisting those subject to it. This issue is becoming increasingly recognized in academic and policy debates on gender and the state. The development of good policy that addresses and considers multiple levels of inequality and marginalization is necessary, though challenging. The intersectionalities involved in multiple inequalities may interfere with each other. What matters is that how these are interrelated has to be seen as a matter for investigation and analysis in each policy context.

In the time period examined, the focus on the UK has involved questions of visibility/ silencing, while the main issue, indeed problem, in the Netherlands is not so much the danger of invisibility of multiple inequalities, but rather a hyper-visibility of gender/ ethnicity intersections in anti-violence policy. In contrast, the Swedish case is characterized by hyper-visibility of gender in policy.

In all cases, class, while being an important intersecting axis of inequality, is often neglected, economic and income inequality is often overlooked, or invisible in policy. In the Swedish case this may be partly explained by higher overall social equality, with relatively small income differences characterizing Nordic societies in international comparison (see Table 1), reflecting the historical and embedded 'taken-for-grantedness' of class equality politics and corporatist class settlement. Race, ethnicity and religion do not override policy on class but rather are often more visible, acting as a locus of policy, and indeed academic, attention.

Moves towards certain kinds of intersectional emphases may also paradoxically bring with them tendencies towards degendering. So what are the implications of degendering? One conclusion is that there needs to be recognition of the different meanings of degendering in different national contexts and between different forms of violence. The three countries differ in their respective approach to what we have called degendering. While policy in the UK from 1997 to 2010 was predominantly degendered, Sweden showed an almost hyper-gendering of policy which in turn silenced the recognition of minoritized women and class. The Netherlands shows a different pattern, with specific exceptions to degendering leading to selective gendering. Degendering in Dutch policy on domestic violence in combination with selective gendering makes the intersection of gender and ethnicity in other forms of violence hyper-visible. By studying anti-violence policy through a lens of intersectionality, country-specific problems and problematizations become visible.

Degendering can happen in general or in intersectionally specific ways. Degendering can mean that gender-specific needs of support for victims or gender-specific ways of addressing perpetrators may be silenced or even become an impossible question. Such an impossibility then is detrimental to the potential quality of policy. 
When policy is degendered, and gender is downplayed or absent, a focus on intersectionality may paradoxically weaken the gender equality project, especially if it reduces the visibility of gender itself. This 'degendered intersectionality' or alternatively making one major single exception to such degendering (as in the case of ethnicity/gender in the Netherlands) can obscure the absences of other intersectional groups, such as lesbian women and women living in poverty. In contrast to such degendered policy, the visibility of a more comprehensive range of interrelations and intersections of multiple, and indeed gendered, inequalities increases the quality of policy on violence against women. This facilitates the making and implementation of policy that concretely targets specific causes and effects of different forms of violence against women.

Without the inclusion of multiple inequalities in policy, violence for the groups at points of intersection is insufficiently and inadequately targeted. Currently, specific and different relative absences are noticeable in the three countries: class and sexuality in the Netherlands; sexuality and disability in Sweden; and class and ethnicity/religion for the UK. As we have seen, theoretical complexity is not always easily translatable into practical policy. The practical challenges of policy development include the uneven power dynamics that follow from emphasis on specific intersections in particular historical contexts. This may shift policies on violence against women from some forms of compartmentalization, but comprehensive policy addressing 'all intersections' for prevention and response to violence against women may remain utopian.

\section{Acknowledgements}

This article is a revised version of a paper presented at the ISA World Conference Yokohama 2014, RC32 Session on 'Interrogating Gender and State in Local, National and Transnational Contexts'. We are grateful to all who commented there, the guest editors and anonymous reviewers. The study stems from the EU QUING (Quality in Gender+ Equality Polices) project, and the Swedish Research Council project, 'Feminist Theorizings of Intersectionality, Transversal Dialogues and New Synergies', a collaboration between the Centre for Feminist Social Studies, Örebro University, and Tema Genus, Linköping University. The empirical policy data from the QUING project were collected by national teams. The Dutch team was led by Mieke Verloo, with Sophie Lauwers and Femke van der Wal as national researchers. The UK team was led by Sylvia Walby, and the national researchers were Jo Armstrong and Sofia Strid. The Swedish team was led by Malin Rönnblom, with Elin Kvist as the national researcher. For a complete list of project national policy documents, see QUING (2007).

\section{Funding}

This research was funded by the Swedish Research Council project, 'Feminist Theorizings of Intersectionality, Transversal Dialogues and New Synergies'.

\section{Notes}

1. Towers and Walby (2012) and the False Economy Project have collected data on which public services are being affected by cuts to public spending. They estimate a reduction in the UK of $31 \%$ of funding to services dealing with domestic violence and sexual abuse between 2010 and 2012. This has inevitably meant fewer refuge places and loss of expert help available to women suffering the effects of gender-related violence. 
2. The UK situation is complicated by differences between England, Northern Ireland, Wales, and especially Scotland, with its own legal system (Hearn and McKie, 2010). The focus here was mainly on England, Northern Ireland and Wales.

3. Alestalo et al. (2009: 6) argue that 'the 1930s represented a political watershed in all Nordic countries with national class compromises between industrial and agricultural/primary sector interests, and between labour and capital through the major trade union federations and employers' associations ... reflected at the parliamentary and governmental level, with political compromises reached across parties representing various class or economic interests'.

\section{References}

Abraham M (2000) Speaking the Unspeakable: Marital Violence among South Asian Immigrants in the United States. New Brunswick, NJ: Rutgers University Press.

Alestalo M, Hort S and Kuhnle S (2009) The Nordic Model: Conditions, Origins, Outcome, Lessons. Berlin: Hertie School of Governance.

Bacchi C (1999) Women, Policy and Politics. London: Sage.

Beckford JA, Gale R, Owen D et al. (2006) Review of the Evidence Base on Faith Communities. London: Office of the Deputy Prime Minister.

$\mathrm{CoE}$ (Council of Europe) (2006) Combating Violence against Women. Stocktaking Study on the Measures and Actions Taken in Council of Europe Member States. Brussels. Available at: www. coe.int/t/dghl/standardsetting/equality/03themes/violence-against-women/CDEG(2006)3 en.pdf (accessed 1 July 2014).

Criminal Code (Brottsbalk) (1962) Svensk författningssamling 1962:700. Justitiedepartementet. Available at: www.riksdagen.se/sv/Dokument-Lagar/Lagar/Svenskforfattningssamling/ Brottsbalk-1962700_sfs-1962-700/.

Dahl U (2005) Scener ur ett äktenskap: Jämställdhet och heteronormativitet. In: Kulick D (ed.) Queersverige. Stockholm: Natur \& Kultur.

Department for Communities and Local Government (2007) Discrimination Law Review. Available at: webarchive.nationalarchives.gov.uk/20120919132719/http://www.communities.gov.uk/pub/244/AFrameworkforFairnessConsultation_id1511244.pdf.

Dombos T, Krizsán A, Verloo M and Zentai V (2009) Critical frame analysis: A comparative methodology for the QUING project. In: ECPR First European Conference on Politics and Gender, Belfast, January.

Dominguez S and Menjivar C (2014) Beyond individual and visible acts of violence. Women's Studies International Forum 44(1): 184-195.

EC (European Commission) (2014) European Commission Actions to Combat Violence Against Women. Brussels. Available at: ec.europa.eu/justice/gender-equality/files/documents/140303_factsheet_vaw_en.pdf(accessed 29 March 2015).

Farnell R, Furbey R, Al-Haq Hills S et al. (2003) 'Faith' in Urban Regeneration. Bristol: Policy Press.

Fernández de Vega A, Lombardo E and Rolandsen Agustin L (2010 [2008]) Report Analysing Intersectionality in Gender Equality Policies for the EU. Vienna: IWM (Institute for Human Sciences).

Government Offices of Sweden (2007) Action Plan for Combating Men's Violence Against Women, Violence and Oppression in the Name of Honour and Violence in Same-Sex Relationships. SKR 2007/08: 39. Stockholm. Available at: www.regeringen.se/rattsdokument/skrivelse/2007/11/skr.-20070839/ (accessed 2 February 2016).

Hearn J (2013) The sociological significance of domestic violence. Current Sociology 16(2): $152-170$. 
Hearn J and McKie L (2008) Gendered policy and policy on gender: The case of 'domestic violence'. Policy and Politics: An International Journal 36(1): 75-91.

Hearn J and McKie L (2010) Gendered and social hierarchies in problem representation and policy processes. Violence Against Women 16(2): 136-158.

Home Office (2003) Safety and Justice: The Government's Proposals on Domestic Violence. London: The Stationery Office.

Home Office (2005a) Domestic Violence: A National Report. London: The Stationery Office.

Home Office (2005b) Forced Marriage: A Wrong not a Right. London: The Stationery Office.

Home Office (2014) A Call to End Violence Against Women and Girls. Action Plan. London: Home Office.

Home Office Faith Communities Unit (2004) Working Together: Co-operation between Government and Faith Communities in 2004. London: Home Office.

Krizsán A, Bustelo M, Hadjiyanni A and Kamoutsi F (2007) Domestic violence. In: Verloo M (ed.) Multiple Meanings of Gender Equality. Budapest: Central European University Press, pp. 141-184.

Kvist E (2010 [2008]) Report Analysing Intersectionality in Gender Equality Policies for Sweden and the EU. Vienna: IWM (Institute for Human Sciences).

Lauwers S and Van der Wal A (2010) Report Analysing Intersectionality in Gender Equality Policies for the Netherlands and the EU. Vienna: IWM (Institute for Human Sciences).

Lombardo E and Meier P (2009) Power and gender: Policy frames on gender inequality in politics in the Netherlands and Spain. Journal of Women, Politics and Policy 30(4): 357-380.

NCK (Nationellt kunskapscenter mot våld) (2014) Hedersrelaterat våld och förtryck. Kunskapsbanken. Uppsala: Uppsala universitet.

QUING (Quality in Gender+ Equality Polices) (2007) List of Documents for Frame Analysis: 29 Countries and the EU. Vienna: IWM (Institute for Human Sciences).

Regeringens Proposition 1997/1995:55. Kvinnofrid. Available at: www.riksdagen.se/sv/ Dokument-Lagar/Forslag/Propositioner-och-skrivelser/Kvinnofrid_GL0355/?text=true (accessed 2 February 2016).

Regeringens Proposition 1998/99:145. Ändring av fridskränkningsbrotten. Available at: www. riksdagen.se/sv/Dokument-Lagar/Forslag/Propositioner-och-skrivelser/ndring-av-fridskrankningsbrot_GM03145/?text=true (accessed 2 February 2016).

Roggeband C and Verloo M (2007) Dutch women are liberated, migrant women are a problem. Social Policy and Administration 41(3): 271-288.

Rolandsen Augustín L (2011) Gender Equality and Diversity at the Transnational Level. Aalborg: Aalborg University.

Sokoloff N and Dupont I (2005) Domestic violence at the intersections of race, class, and gender. Violence Against Women 11(1): 38-64.

Strid S, Armstrong J and Walby S (2009) Frame comparison between the EU and the UK. Quality in Gender+ Equality Policy Project (QUING). LARG research report delivered to the European Commission.

Strid S, Armstrong J and Walby S (2010 [2008]) Report Analysing Intersectionality in Gender Equality Policies for the United Kingdom and the EU. Vienna: IWM (Institute for Human Sciences).

Strid S, Walby S and Armstrong J (2013) Intersectionality and multiple inequalities: Visibility in British policy on violence against women. Social Politics 20(4): 558-581.

Towers J and Walby S (2012) Measuring the impact of cuts in public expenditure on the provision of services to prevent violence against women and girls. Report for the Northern Rock Foundation and Trust for London. Available at: www.nr-foundation.org.uk/resources/publications/domestic-abuse-research-reports/ (accessed 29 March 2015). 
UNDP (United Nations Development Programme) (2014) Human Development Report 2014. Sustaining Human Progress: Reducing Vulnerability and Building Resilience. New York: UNDP.

Van der Haar M and Verloo M (2013) Unpacking the Russian doll: Gendered and intersectionalized categories in European gender equality policies. Politics, Groups, and Identities 1(3): 417-432.

Verloo M (2006) Multiple inequalities, intersectionality and the European Union. European Journal of Women's Studies 13(3): 211-228.

Verloo M (ed.) (2007) Multiple Meanings of Gender Equality: A Critical Frame Analysis of Gender Policies in Europe. Budapest: Central European University Press.

Verloo M and Walby S (2012) Introduction: The implications for theory and practice of comparing the treatment of intersectionality in the equality architecture in Europe. Social Politics 19(4): 433-455.

Walby S (2007) A Review of Theory and Methodology for the Analysis of the Implications of Intersectionality for Gender Equality Policies in the EU. Report D13 and D14 for the European Commission. Vienna: IWM (Institute for Human Sciences).

Walby S (2009) Globalization and Inequalities: Complexity and Contested Modernities. London: Sage.

Walby S, Armstrong J and Strid S (2012a) Intersectionality: Multiple inequalities in social theory. Sociology 46(2): 224-240.

Walby S, Armstrong J and Strid S (2012b) Intersectionality and the quality of the gender equality architecture. Social Politics 19(4): 446-481.

Watts C and Zimmermann C (2002) Violence against women: Global scope and magnitude. The Lancet 359(9313): 1232-1237.

World Economic Forum (2014) Global Gender Gap Report 2014. Geneva: World Economic Forum. Available at: www3.weforum.org/docs/GGGR14/GGGR_CompleteReport_2014.pdf.

Yanow D and Van der Haar M (2013) People out of place: Allochthony and autochthony in the Netherlands' identity discourse. Journal of International Relations and Development 16(2): 227-261.

Yuval-Davis N (2006) Intersectionality and feminist politics. European Journal of Women's Studies 13(3): 193-210.

\section{Author biographies}

Jeff Hearn is Guest Research Professor, Faculty of Humanities and Social Sciences, based in Gender Studies, Örebro University, Sweden; Research Professor of Sociology at the University of Huddersfield, UK; and Professor Emeritus at Hanken School of Economics, Helsinki, Finland. His latest books are Rethinking Transnational Men (edited with Marina Blagojević and Katherine Harrison, Routledge, 2013) and Men of the World: Genders, Globalizations, Transnational Times (Sage, 2015).

Sofia Strid is Associate Professor of Gender Studies at Örebro University, Sweden; Co-Director of GEXcel International Collegium for Advanced Transdisciplinary Gender Studies; academic lead of FATIMA: Preventing Honour-Based Violence through Education and Dialogue (2014-2017) (DAPHNE-funded); and a researcher on many EU projects on violence. She is chief editor of Tidskrift för Genusvetenskap [Journal for Gender Studies], and co-author of Stopping Rape (Policy Press, 2015).

Liisa Husu is Professor of Gender Studies, Co-Director of GEXcel International Collegium for Advanced Transdisciplinary Gender Studies, and Leader of the Centre for Feminist Social Studies, Örebro University, Sweden. She has been engaged in several European research projects, and been an international policy expert. Her publications include: Sexism, Support and Survival in Academia (2001), Hard Work in the Academy (1998) and Leadership through the Gender Lens (2010). 
Mieke Verloo is Professor of Comparative Politics and Inequality Issues at Radboud University, the Netherlands, and Non-Residential Permanent Fellow at the IWM, Institute for Human Sciences, Vienna. She was scientific director of large research projects on gender equality policy-making in Europe (www.mageeq.net, www.quing.eu). With Emanuela Lombardo and Petra Meier she edited The Discursive Politics of Gender Equality: Stretching, Bending and Policymaking (Routledge, 2009).

\section{Résumé}

En s'appuyant sur des travaux de recherche féministes sur l'intersectionnalité, cet article examine la violence envers les femmes et les réponses politiques de l'État. II relève le défi que constitue l'analyse de la relation située, spatiale et complexe entre la théorisation de la violence faite aux femmes et les politiques étatiques de lutte contre ces violences. À partir de données européennes, comparatives et détaillées, ce travail explore les relations entre le genre et l'intersectionnalité, qui sont conceptualisées sous la forme d'intersectionnalités de genre, et il examine les niveaux de visibilitéé et d'invisibilité des multiples inégalités sont rendues dans les politiques de l'État et le débat public aux Pays-Bas, en Suède et au Royaume-Uni. II accorde une attention particulière aux différentes formes d'intersectionnalités du genre dans la politique publique, par exemple à la tentation de désexualiser la violence faite aux femmes. L'un des principaux objectifs de cet article est de comprendre dans quelle mesure une analyse comparative pourrait servir de point de départ pour évaluer la pertinence de l'inclusion des inégalités multiples pour améliorer les politiques visant à réduire ou à faire cesser la violence et à aider celles qui en sont victimes.

\section{Mots-clés}

Études comparatives, Europe, intersectionnalité, politiques, violence contre les femmes

\section{Resumen}

Este trabajo se basa en los estudios feministas sobre interseccionalidad para abordar la violencia contra las mujeres, y la política del Estado al respecto. Asume el reto de analizar la relación compleja, localizada y ordenada entre la teorización sobre la violencia contra la mujer y la política del Estado en este tipo de violencia. Basándose en extensos datos comparativos europeos, explora las relaciones de género y la interseccionalidad, conceptualizadas como interseccionalidades de género, examinando cómo las múltiples desigualdades se hacen visibles e invisibles en la política estatal y en los debates en los Países Bajos, Suecia y el Reino Unido. Se presta atención a las diferentes interseccionalidades de género en la política, por ejemplo, tendencias a la generalización de la violencia contra las mujeres. Un objetivo clave de este trabajo es investigar cómo el análisis comparativo puede ser un punto de partida para evaluar si, cómo y en qué medida la inclusión de múltiples desigualdades podría aumentar la calidad de la política, tanto para reducir y detener la violencia, como para ayudar a aquellos que están sujetos a violencia.

\section{Palabras clave}

Comparativos, Europeos, interseccionalidad, política, violencia contra las mujeres 